Received June 28, 2017

Revised November 16, 2017

Accepted November 30, 2017

\title{
Institutional Quality Matters: Evidence from Trade Flows of ASEAN-6 Countries*
}

\author{
NGUYEN T. T. HUYEN ${ }^{* *} \cdot$ TRAN N. KIEN ${ }^{* * *} \cdot$ YOON HEO ${ }^{* * * *}$
}

This study examines the impacts of institutional quality on export patterns of ASEAN-6 countries using panel data from 115 economies over the period 2000-2012. The results of the fixed and random effects estimation methods show that better institutional quality in ASEAN's trading partners plays a crucial role in the bloc's export performance. By decomposing institutional quality using different components, we also find that the importers' legal structure and protection of property rights as well as freedom to trade internationally are important determinants in attracting more exports from ASEAN countries. For exporting countries, the sizes of the government and freedom to trade internationally also play a critical role in boosting trade from the bloc.

Keywords: Institution Quality, Trade Flows, Asean-6, Fixed Effects, Random Effects

* An earlier version of this paper was presented at Sogang IIAS Research Series in December 2015.

** Faculty of Economics, Thai Nguyen University of Economics and Business Administration, Thainguyen, Vietnam; E-mail: ntthuyen@tueba.edu.vn

*** Associate Professor, Thai Nguyen University of Economics and Business Administration, Thainguyen, Vietnam; E-mail: tnkien@tueba.edu.vn

****Corresponding Author, Professor, Graduate School of Intl's Studies, Sogang University, Seoul, Korea; Email: hury@sogang.ac.kr

DOI: $10.16934 /$ isr.18.2.201712.21 


\section{INTRODUCTION}

In recent years, the role of institutions has received more attention from not only the economic performance perspective, which explains the differences in per capita income across countries (Acemoglu et al., 2001; Rodrik et al., 2004; Lee and Kim, 2009), but also from their impact on international trade flows. The notion of institutions is defined by North (1994, p. 360) as "the humanly devised constraints that structure human interaction. They are made up of formal constraints (e.g., rules, laws, and constitutions), informal constraints (e.g., norms of behavior, conventions, and self-imposed codes of conduct), and their enforcement characteristics. Together, they define the incentive structure of societies and specifically economies." The term refers to a broad range of aspects when investigating its nexus with the patterns of trade, such as insecurity (Anderson and Marcouiller, 2002), property rights (de Groot et al., 2004), contract enforcement (Levchenko, 2007; Ranjan and Lee, 2007), and democracy (Yu, 2010).

The literature on institutional quality and trade may be classified into two strands. The first strand addresses how trade liberalization affects the institutional quality of trading partners. Cheptea (2007) demonstrates that national institutions have a strong and significant impact on trade between European countries. Do and Levchenko (2009) provide theoretical evidence showing that trade openness may be detrimental to institutional quality when firms differ with regard to their productivity, which in their model directly changes the level of political power. The second strand of this literature focuses on the importance of institutional quality in explaining the variation in trade flows. The pioneer study on this aspect is Anderson and Marcouiller (2002). They combine the analysis of the impact of corruption and imperfect contract enforcement in a theoretical model with empirical estimates of the impact of institutions on trade patterns, and conclude that inadequate institutions constrain trade as much as tariffs do. Later works by de Groot et al. (2004, 2005), Ranjan and Lee (2007), Levchenko (2007, 2013), and $\mathrm{Yu}(2010)$ illustrate that institutional differences are an important determinant of trade. The difference in trade data used by these works lies in Rauch's classification (Ranjan and Lee, 2007) by industry-level trade (Nunn, 2007; Mendonca et al., 2014) or trade volumes (de Groot et al., 2004; Levchenko, 2007).

Motivated by related literature, our study aims to investigate the impact of institutional quality on trade flows, focusing on the Association of Southeast Asian Nations (ASEAN), which consists of ten members. ${ }^{1}$ Over the last decade, the bloc's trade flows have increased steadily (Appendix A 1) with major trading partners such as Japan, China, the US, and the EU (Appendix A 2). The volume of intra-ASEAN trade has also tripled since the establishment of the ASEAN Free 
Trade Area in 1992. A study by Huang et al. (2004) shows that ASEAN countries suffer from state activism, poor property right protection, and under-developed corporate governance with an exception of Singapore. A poor institutional environment may aggravate the effects of an external shock. In order to promote ASEAN's exports, Nguyen and Tran (2012) recommend strengthening intellectual property right protection in foreign countries accompanied by improving social infrastructure and accelerating trade openness in ASEAN countries.

Our study intends to contribute to the existing literature in terms of the following points. First, using panel data of 115 partners, which have bilateral trade with ASEAN-6 member countries (Indonesia, Malaysia, Philippines, Singapore, Thailand, and Vietnam) over the period 2000-2012, we employ an extended gravity model to show that institutional quality significantly determined trade flows in ASEAN countries, but differently at various stages of economic development. Second, we support our findings in terms of an empirical methodology by using a supportive fixed-effects panel estimation.

The paper is organized as follows. Section 2 provides a more detailed discussion of the measurement of institutional quality and its relationship with ASEAN trade flows. Section 3 introduces the methodology for empirical analysis of the data as well as the findings based on the estimated results. Finally, section 4 concludes the paper with a summary and some final remarks.

\section{LITERATURE REVIEW}

The nexus of institutions and international trade flows has been discussed widely in literature during recent times. Anderson and Marcouillier (2002) were among the first contributors to show that bilateral trade volumes are positively influenced by the trading countries' institutional quality. Using data drawn from the World Economic Forum 1997 Executive Survey to measure the quality of institutions across 48 countries, they find that a $10 \%$ increase in the transparency and impartiality index of a country leads to a 5\% rise in its volume, when other things remain equal. The costs associated with institutional inefficiencies explain why countries trade so little. Later work by de Groot et al. (2004) and Jansen and Nordas (2004) confirms their findings. De Groot et al. (2004) employ a gravity model approach to estimate the effect of institutional quality on trade flows for a set of more than 100 countries in 1998 . They find that institutional quality and the quality of governance has a positive, significant, and substantial impact on bilateral trade flows. In focusing on the country-specific quality of institutions and bilateral homogeneity of governance, they show that the large divergence in institutions' effectiveness reduces trade.

Looking at a particular aspect of the institution and quality of contract enforcement, Ranjan and Lee (2007) adopt Rauch's (1999) classification to 
classify traded goods into three types: organized exchange, reference priced, and differentiated goods with the presumption that the last category is most sensitive to contract enforcement issues. Using various proxies for contract enforcement, they find that bilateral trade volumes are most affected by the class of differentiated goods.

Levchenko (2007) states that countries with better quality of institutions capture higher US import shares in more institutionally dependent industries. High institutional quality, including contract enforcement, rule of law, and the protection of property rights can reduce the risks of a lack of fulfillment of the terms of the contract for both international trading patterns, which in turn can foster trade. Additionally, focusing on contract enforcement, Nunn (2007) examines whether countries with better contract enforcement specialize in the production of goods for which relationship-specific investments are important. The research finds that contract enforcement explains more of the pattern of trade than countries' combination of capital and skilled labor endowment. Levchenko (2013) also demonstrates that trade opening can lead to institutional improvement due to a foreign competition effect.

Democratic institutions have also been proven to a have positive influence on trade by $\mathrm{Yu}$ (2010). By examining the industrial trade flows among 157 countries for the period 1962-1998 in a theoretically-grounded gravity equation and controlling for the endogeneity of democracy, he finds that trading countries' democratization contributes 3-4\% overall to bilateral trade growth.

Using indicators of institutional quality from the Economic Freedom of the World (EFW) database as well as following Gwartney and Lawson (2003), Gwartney et al. (2004), and Gwartney (2009), Doyle and Martinez-Zarzoso (2011) measure institutional quality based on four out of five dimensions ${ }^{2}$ during the period 1980-2000. They find that countries with low institutional quality benefit from openness to trade and that the positive effect of trade on labor productivity is lower for more populated countries. François and Manchin (2013) use a Poisson estimator to examine the influence of institutional quality and infrastructure on patterns of trade. They find that better institutional quality in the exporting country plays a crucial role in the country's export performance.

In order to explain the dynamics of the east Asian industrializing countries (including China and excluding Japan), Filippini and Molini (2003) use a gravity equation model to analyze trade flows between East Asia and developed countries to demonstrate that the trade flows are determined by the technological gap. 


\section{INSTITUTIONAL QUALITY ASEAN TRADE FLOWS NEXUS}

\section{The Model}

To estimate the effect of institutional quality on ASEAN trade flows, we rely on the gravity model, which originally explained the nexus between trade flows and GDP of the pair of trading countries, taking into account other determinants of trade such as distance and other pair-specific factors. ${ }^{3}$ The standard version of the gravity model takes the following form:

$$
\text { Trade }_{i j}=\beta_{0} G D P_{i}^{\beta_{1}} G D P_{j}^{\beta_{2}} D I S T_{i j}^{\beta_{3}} A_{i j}^{\beta_{3}} u_{i j}
$$

where $i$ and $j$ denote the exporting and importing countries respectively. The dependent variable Trade $_{i j}$ is bilateral trade flows (exports, imports, or total trade). The independent variables $G D P_{i}, G D P_{j}, D I S T_{j}, A_{i j}$ and $u_{i j}$ are the gross domestic products of the exporting and importing countries, distance between countries $i$ and $j$, constant of proportionality, and disturbance term, respectively.

In recent literature, the gravity model has been extensively extended by including other variables to explain the main determinants of trade such as democracy (Yu, 2010), institutional quality (Anderson and Marcouiller, 2002; Ranjan and Lee, 2003; de Groot et al., 2004), and technological distance (Filippini and Molini, 2003). In this research, our method broadly follows that of Francois and Manchin (2013) and Doyle and Martinez-Zarzoso (2011) by adding institutional quality to the gravity model to investigate the role of institutions on ASEAN trade flows nexus. Using the logarithmic transformation, the gravity equation is expressed as follows:

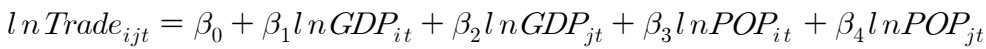

$$
\begin{aligned}
& +\beta_{5} \text { ln Dist }_{i j}+\beta_{6} \text { Language }_{i j}+\beta_{7} \text { Colony }_{i j}+\beta_{8} \text { Com Col }_{i j} \\
& +\beta_{9} \text { Adjacency }_{i t}+\beta_{9} \ln I N S T_{i t}+\beta_{10} \ln I N S T_{j t}+u_{i j t}
\end{aligned}
$$

where $i$ denotes the exporter, $j$ denotes the importer, and $t$ denotes the year. The variables are defined as follows:

Trade $_{i j t}$ is the real volume of directional export from country $i$ to $j$ in year $t$.

$G D P_{i t}$ is the real gross domestic product for country $i$ in year $t$.

$G D P_{j t}$ is the real gross domestic product for country $j$ in year $t$.

$P O P_{i t}$ is the exporting country $i$ 's population in year $t$.

$P O P_{j t}$ is the importing country $j$ 's population in year $t$.

$D I S T_{i j}$ is the geographical distance between the capital cities of countries $i$ and $j$ Language $_{i j}$ is a dummy variable that is unity if countries $i$ and $j$ share a common 
language spoken by at least $9 \%$ of the population in both countries, and zero otherwise.

Co $l o n y_{i j}$ is a dummy variable that is unity if the exporting country $i$ was a colony of the partner country $j$ or vice versa, and zero otherwise.

$\mathrm{Com} \mathrm{Col}_{i j}$ is a dummy variable that is unity if the exporting country $i$ and the importing country $j$ were ever colonies after 1945 with the same colonizer, and zero otherwise.

Adjacency $_{i j}$ is a dummy variable that is unity if the exporting country $i$ shares a land border with the partner country $j$, and zero otherwise.

$I N S T_{i t}$ is the institutional quality of the exporting country $i$ in year $t$.

$I N S T_{j t}$ is the institutional quality of importing country $j$ in year $t$.

$u_{i j t}$ represents the other omitted influences on ASEAN trade flows in year $t$.

We estimate the gravity equation using a fixed effects model with the assumption of the correlation between heterogeneity and the regressors. The Breusch-Pagan Lagrange multiplier test helps us to decide between random effects and simple OLS regressions. Furthermore, a Hausman test allows us to decide between fixed or random effects. The null hypothesis rejection of the Hausman test helps us to eliminate the random effects hypothesis and indicates that fixed effects estimation is appropriate. ${ }^{4}$ In order to address the potential biases associated with cross-section estimations such as small sample bias and omitted variable problems, we use fixed effects estimation methods.

\section{Data}

The panel data comprises 115 countries that are bilateral trading partners with ASEAN. We include ASEAN-6 over the period from 2000-2012 and exclude some of the emerging ASEAN countries because of data availability.

Data on trade flows are compiled from the UN COMTRADE database. The trade data are the volume of exports from ASEAN-6 to its partners by the Standard International Trade Classification (SITC) revision 2. Unfortunately, it is measured in US dollars. We deflate the trade data with the American Consumer Price Index (CPI) for all urban consumers $(1982-1984=100)$ which are sourced from the US Bureau of Labor Statistics ${ }^{5}$ to obtain the real trade value.

Data on gross domestic product (GDP) and population come from the World Development Indicators (World Bank, 2015). However, the World Bank (2015) specifies GDP data in the base year of the American CPI as 2005. We thus converted current GDP in US\$ by dividing by the American CPI to get real GDP; this is consistent with the real trade data described above. The distance data, together with dummies for common languages, colony, common colonizer, and 
adjacency are taken from Mayer and Zignago (2011). The simple distance data are calculated following the great circle formula, which uses latitudes and longitudes of the most important cities or of the official capital of each country.

For the institutional quality variables, we have acquired data from the EFW database sponsored by the Fraser Institute. In comparison to the institutional data from Kaufmann et al. (2009), the EFW index is supplemented with robustness checks and is the longest time series data suitable for the time span of our inquiry. It is calculated using a weighted average of the following five major components of economic freedom, reflecting the policies and institutions of countries: (1) size of government: expenditures, taxes, and enterprises; (2) legal structure and security of property rights; (3) access to sound money: money growth, inflation, and freedom to own foreign currency bank accounts; (4) freedom to trade internationally: tariffs, regulatory trade barriers, black-market exchange rates, and control of the movement of capital and people; and (5) regulation of credit, labor, and business. Each major component is placed on a scale from 0 to 10 wherein higher values equal a higher degree of an institutionalized economy. Data are available annually over the period 20002012.

Panel A of Table 1 summarizes the mean, standard deviation, minimum, and maximum values of the dependent and independent variables employed in the estimated models; panel B contains the correlation matrix. As we can observe, the correlation between the institutional quality of the importing countries and ASEAN trade flows is low. The export flows of ASEAN countries almost have no correlation with other gravity variables. This suggests that the issue of multicollinearity is not present in the dataset. The list of trading partners with ASEAN included in our estimations is provided in the Appendix, A3. 


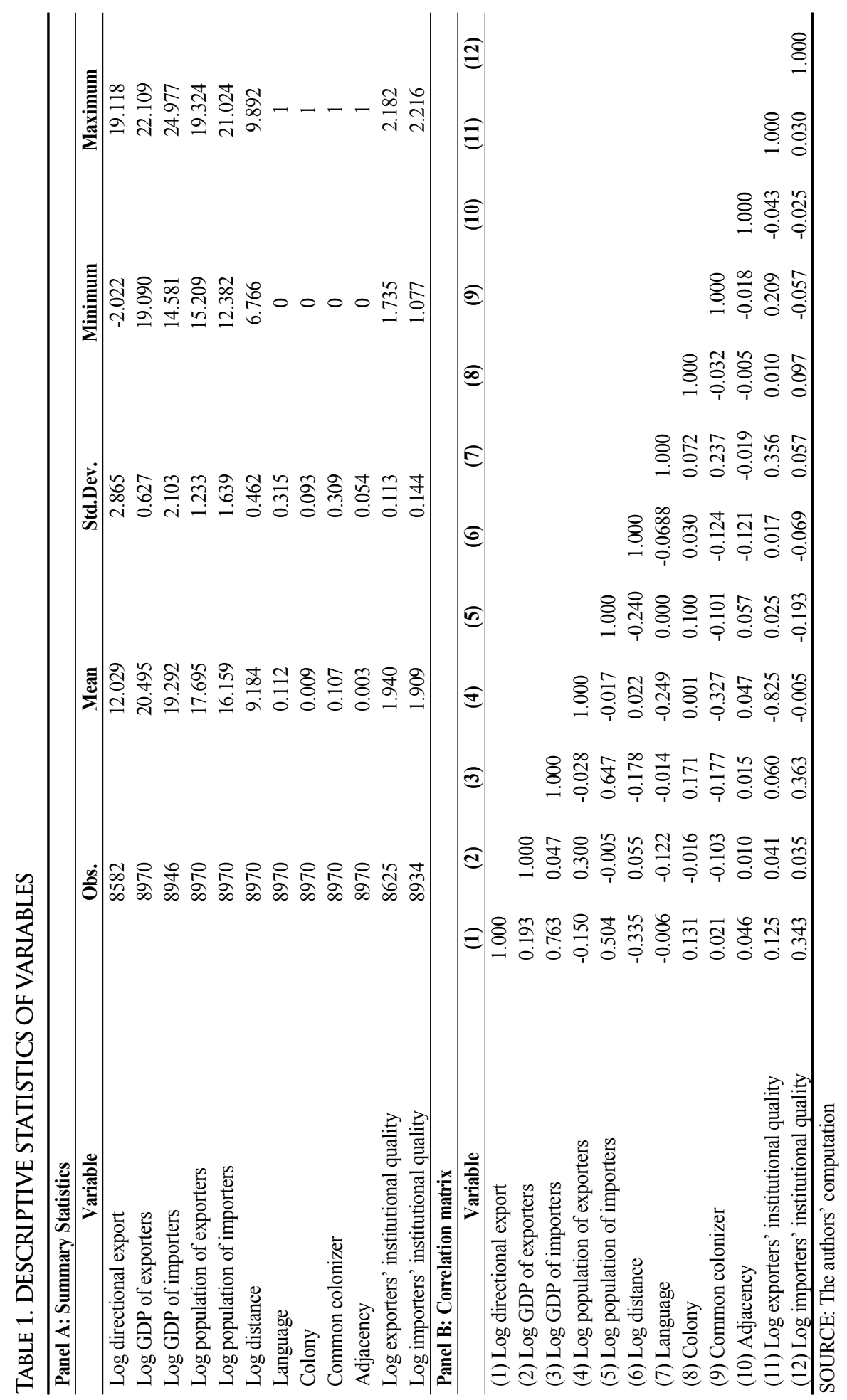




\section{Estimation Results and Discussions}

The estimation results are presented in Table 2. The first two columns present results based on simple OLS regressions with and without the institutional quality variable. All coefficients have the expected signs and are significant except for the sign on the population of importers when we add the institutional variable. The coefficients of GDP of both exporting and importing countries are positive, suggesting that ASEAN trade is positively related to the market size of importing countries. A significant negative coefficient on the distant variable indicates that ASEAN countries export less to partners due to a higher transportation cost, time, and access to relevant market information.

Colony, common colonizer of both exporting and importing countries, and common border are positively significant in all specifications. For the population variables, we obtain a significant negative coefficient for both the exporters and their trading partners, but the sign on the population of importers becomes positive in the second specification (even with the fixed or random effects estimation, which are reported in the last two columns of the table). The positively significant coefficient on the institutional quality of ASEAN trade suggests that better institutional quality of the trading partners plays an important role in ASEAN's export performance. The result also shows the negative significant relationship between the institutional qualities of ASEAN countries with the bloc's export performance.

The last column of Table 2 also reports the results of the Breusch-Pagan Lagrangian multiplier (LM) and Hausman tests, which have been discussed in the previous section. The result of the Breusch-Pagan LM test indicates that the random model is preferred to the simple OLS regression. Nevertheless, a Hausman test of fixed versus random effects specification indicates that the former estimation is appropriate. Therefore, we prefer the fixed effects specification.

\section{TABLE 2. ESTIMATION RESULTS OF OLS, FE, AND RE ESTIMATIONS}

\begin{tabular}{|c|c|c|c|c|}
\hline Regressand & \multicolumn{2}{|c|}{ OLS } & \multirow{2}{*}{$\mathrm{FE}$} & \multirow{2}{*}{$\mathrm{RE}$} \\
\hline Log directional exports & (1) & (2) & & \\
\hline Log GDP of exporters & $\begin{array}{c}1.099 * * * \\
(40.01)\end{array}$ & $\begin{array}{c}1.679 * * * \\
(46.22)\end{array}$ & $\begin{array}{c}0.0684 * * * \\
(10.94)\end{array}$ & $\begin{array}{c}0.644 * * * \\
(16.37)\end{array}$ \\
\hline Log GDP of importers & $\begin{array}{c}1.007 * * * \\
(92.72)\end{array}$ & $\begin{array}{c}0.897 * * * \\
(64.80)\end{array}$ & $\begin{array}{c}0.892 * * * \\
(19.28)\end{array}$ & $\begin{array}{c}0.901 * * * \\
(30.62)\end{array}$ \\
\hline Log population of exporters & $\begin{array}{c}-0.398 * * * \\
(-25.78)\end{array}$ & $\begin{array}{c}-1.167 * * * \\
(-36.94)\end{array}$ & $\begin{array}{c}-1.177 * * * * \\
(-4.31)\end{array}$ & $\begin{array}{c}-0.445 * * * \\
(-7.99)\end{array}$ \\
\hline Log population of importers & $\begin{array}{c}-0.029 * * \\
(-2.18)\end{array}$ & $\begin{array}{c}0.098 * * * \\
(5.83)\end{array}$ & $\begin{array}{l}0.121 \\
(0.86)\end{array}$ & $\begin{array}{c}0.078^{*} \\
(1.88)\end{array}$ \\
\hline Log distance & $\begin{array}{c}-1.247 * * * \\
(-32.88)\end{array}$ & $\begin{array}{c}-1.147 * * * \\
(-30.61)\end{array}$ & & $\begin{array}{c}-1.195 * * * \\
(-9.63)\end{array}$ \\
\hline Language & $\begin{array}{c}-0.498 * * * \\
(-8.66)\end{array}$ & $\begin{array}{l}0.082 \\
(1.36)\end{array}$ & & $\begin{array}{c}-0.569 * * * \\
(-3.09)\end{array}$ \\
\hline Colony & $\begin{array}{c}0.701 * * * \\
(3.89)\end{array}$ & $\begin{array}{c}0.560 * * * \\
(3.30)\end{array}$ & & $\begin{array}{l}0.769 \\
(1.29)\end{array}$ \\
\hline
\end{tabular}




\begin{tabular}{|c|c|c|c|c|}
\hline Regressand & & & FF & $\mathrm{PF}$ \\
\hline Log directional exports & $(1)$ & $(2)$ & $\mathrm{FE}$ & $\mathrm{KE}$ \\
\hline Common colonizer & $\begin{array}{c}0.979 * * * \\
(15.99)\end{array}$ & $\begin{array}{c}0.667 * * * \\
(10.92)\end{array}$ & & $\begin{array}{c}0.746^{* * * *} \\
(3.84)\end{array}$ \\
\hline Adjacency & $\begin{array}{l}0.913 * * * \\
(2.96)\end{array}$ & $\begin{array}{l}0.998 * * * \\
(3.20)\end{array}$ & & $\begin{array}{l}0.876 \\
(0.86)\end{array}$ \\
\hline Log exporters' institutional quality & & $\begin{array}{c}-9.379 * * * \\
(-27.38)\end{array}$ & $\begin{array}{l}-0.157 \\
(-0.46)\end{array}$ & $\begin{array}{c}-0.858 * * * \\
(-2.61)\end{array}$ \\
\hline Log importers' institutional quality & & $\begin{array}{c}2.003 * * * \\
(12.78)\end{array}$ & $\begin{array}{c}0.869 * * * \\
(4.77)\end{array}$ & $\begin{array}{c}1.001 * * * \\
(5.76)\end{array}$ \\
\hline Constant & $\begin{array}{c}-11.09 * * * \\
(-15.71)\end{array}$ & $\begin{array}{l}4.073 * * * \\
(3.84)\end{array}$ & $\begin{array}{c}-1.079 * * * \\
(-0.39)\end{array}$ & $\begin{array}{l}-1.366 \\
(-0.79)\end{array}$ \\
\hline$R^{2}$ & 0.706 & 0.729 & 0.326 & 0.325 \\
\hline Number of observations & 8558 & 8196 & 8196 & 8196 \\
\hline $\begin{array}{l}\text { Breusch-Pagan LM } \\
\text { Prob. }\end{array}$ & & & & $\begin{array}{c}22414.32 \\
0.000\end{array}$ \\
\hline $\begin{array}{l}\text { Hausman } \\
\text { Prob. } \\
\end{array}$ & & & & $\begin{array}{c}194.24 \\
0.000 \\
\end{array}$ \\
\hline
\end{tabular}

SOURCE: Regression results

NOTES: a. t-value is in parentheses.

b. ${ }^{*}, * *$ and ${ }^{* *}$ indicate significance at the $0.1,0.05$, and 0.01 levels, respectively.

Looking at the results of the fixed effects estimation, the institutional quality of importing countries retains its expected positive signs and is significant at the $1 \%$ level. The institutional quality of ASEAN countries turns out to be negatively insignificant. Both exporters' and importers' GDPs are correctly signed and show significant effects on ASEAN exports. The population of exporters' coefficient is strongly negative and significant at the $1 \%$ level, while that of importers is positive but insignificant.

Table 3 reports the results of the fixed effect estimation, which is used to control for omitted variables that differ between countries but are constant overtime using different components of institutional quality as discussed in section 3. The GDP coefficients are consistent with the literature. The significantly positive coefficient on the institution of importing countries measured by the legal system, property rights, and freedom to trade internationally suggests once more that countries with a high protection of property rights and high openness to trade attract ASEAN exports. The size of the government, sound money, and regulation components maintain their positive effect on trade flows, but are insignificant.

However, the results also show that the negatively significant relationship between the legal system and property rights as well as the regulation of ASEAN, is detrimental to trade flows from the bloc. On the other hand, the size of the government and freedom to trade internationally emphasize their important roles in the trade between the bloc and its partners. The signs and magnitudes of the population variables refer to a strong negative relationship between ASEAN exports and its population size, while there is an insignificant, but positive nexus between ASEAN trade flows and the population of importing countries. 
TABLE 3. ESTIMATION RESULTS USING DIFFERENT COMPONENTS OF INSTITUTIONAL QUALITY

\begin{tabular}{lccccc}
\hline & $\begin{array}{c}\text { Size of } \\
\text { Government }\end{array}$ & $\begin{array}{c}\text { Legal System } \\
\text { \&Property } \\
\text { Rights }\end{array}$ & $\begin{array}{c}\text { Sound Money } \\
\text { Freedom to } \\
\text { Trade } \\
\text { Internationally }\end{array}$ & Regulation \\
\hline Log GDP of exporters & $0.477^{* * *}$ & $0.708^{* * *}$ & $1.009^{* * *}$ & $0.665^{* * *}$ & $0.858^{* * *}$ \\
& $(9.22)$ & $(13.67)$ & $(17.30)$ & $(13.17)$ & $(16.44)$ \\
Log GDP of importers & $0.913^{* * *}$ & $0.927 * * *$ & $0.866^{* * *}$ & $0.951^{* * *}$ & $0.962^{* * *}$ \\
& $(20.66)$ & $(20.87)$ & $(18.98)$ & $(21.77)$ & $(21.44)$ \\
Log population of exporters & $-0.848^{* * *}$ & $-0.997 * * *$ & $-2.565^{* * *}$ & $-1.242^{* * *}$ & $-1.584 * * *$ \\
& $(-3.26)$ & $(-3.79)$ & $(-8.97)$ & $(-4.75)$ & $(-6.03)$ \\
Log population of importers & 0.067 & 0.020 & 0.079 & 0.056 & 0.084 \\
& $(0.48)$ & $(0.14)$ & $(0.56)$ & $(0.40)$ & $(0.60)$ \\
Log exporters' institutional quality & $\mathbf{1 . 8 3 2 * * *}$ & $\mathbf{- 0 . 5 1 4 * * *}$ & $\mathbf{- 1 . 4 8 0}$ & $\mathbf{2 . 3 1 4 * * *}$ & $\mathbf{- 1 . 5 5 7 * * *}$ \\
& $\mathbf{( 1 3 . 6 0 )}$ & $\mathbf{( - 5 . 0 2 )}$ & $\mathbf{( - 1 2 . 0 4 )}$ & $\mathbf{( 8 . 2 7 )}$ & $\mathbf{( - 9 . 2 9 )}$ \\
Log importers' institutional quality & $\mathbf{0 . 0 6 1}$ & $\mathbf{0 . 2 8 1 * * *}$ & $\mathbf{0 . 0 5 6}$ & $\mathbf{0 . 5 0 7 * * *}$ & $\mathbf{0 . 6 2 6}$ \\
& $\mathbf{( 0 . 8 7 )}$ & $\mathbf{( 3 . 9 2 )}$ & $\mathbf{( 0 . 6 8 )}$ & $\mathbf{( 5 . 1 6 )}$ & $\mathbf{( 4 . 9 3 )}$ \\
Constant & -5.194 & -2.670 & $21.605 * * *$ & -4.433 & 4.339 \\
& $(-1.28)$ & $\mathbf{( - 0 . 6 5 )}$ & $(4.81)$ & $(-1.08)$ & $(1.05)$ \\
$R^{2}$ & 0.343 & 0.328 & 0.338 & 0.333 & 0.348 \\
Number of observations & 8208 & 8196 & 8176 & 8191 & 8317 \\
\hline
\end{tabular}

SOURCE: Regression results

NOTES: a. $t$-value is in parentheses.

b. ${ }^{*}, * *$, and ${ }^{* * *}$ indicate significance at the $0.1,0.05$, and 0.01 levels, respectively.

c. Regressors for distance, common language, colony, common colonizer, and adjacency are omitted in fixed effects estimation.

\section{CONCLUSIONS}

Using an augmented gravity model, this study investigates the impacts of institutional quality on the trade flows of ASEAN-6. With a rich data set over the 2000-2012 period, our finding supports the conclusion that ASEAN trade flows is significant and positively related to the institutional quality of its trading partners. The result of the fixed effects estimation using five different components of institutional quality, suggests that the legal structure and security of property rights as well as freedom to trade internationally, such as tariffs, regulatory trade barriers, and the black market exchange rate of importing countries play a crucial role in attracting export from ASEAN countries.

The results also imply that the size of the government reflected by expenditure, taxes, and enterprises as well as freedom to trade boost export performance. The legal system and regulations deter trade flow from ASEAN countries. We also show that the population of exporters is detrimental to their exports while that of importers is benefited by ASEAN exports. Our findings also imply that ASEAN's exports would increase further when the importing countries' institutional quality is strengthened in terms of their sound monetary policy and regulatory environment. 


\section{REFERENCES}

Acemoglu, Daron, Simon Johnson and James A. Robinson. 2001. "The Colonial Origins of Comparative Development: An Empirical Investigation." American Economic Review 91(5): 1369-1401.

Anderson, James E. and Douglas Marcouiller. 2002. "Insecurity and the Pattern of Trade: An Empirical Investigation." The Review of Economics and Statistics 84(2): 342-352.

Anderson, James E. and Eric van Wincoop. 2003. "Gravity with Gravitas: A Solution to the Border Puzzle." The American Economic Review 93(1): 170-192.

Cheptea, A. 2007. "Trade liberalization and institutional reforms." Economic of Transition 15(2): 211-255.

De Groot, Henri L. F., Gert-Jan Linders, Piet Rietveld and Uma Subramanian. 2004. "The Institutional Determinants of Bilateral Trade Patterns." Kyklos 57(1): $103-124$.

De Groot, Henri L. F., Gert-Jan M. Linders and Piet Rietveld. 2005. "Institutions, Governance and International Trade - Opening the Black Box of OECD and GDP per Capita Effects in Gravity Equations." Journal of International Association of Traffic and Safety Sciences 29(2): 22-27.

Do, Quy-Toan and Andrei A. Levchenko. 2009. "Trade, Inequality, and the Political Economy of Institutions." Journal of Economic Theory 144: 14891520.

Dollar, David and Aart Kraay. 2003. "Institution, Trade, and Growth." Journal of Monetary Economics 50: 133-162.

Doyle, Eleanor and Inmaculada Martinez-Zarzoso. 2011. "Productivity, Trade, and Institutional Quality: A Panel Analysis." Southern Economic Journal 77(3): 726-752.

Filippini, Carlo and Vasco Molini. 2003. "The Determinants of East Asian Trade Flows: a Gravity Equation Approach." Journal of Asian Economics 14: 695-711.

Francois, Joseph and Miriam Manchin. 2013. "Institutions, Infrastructure, and Trade." World Development 46, 165-175.

Gwartney, James D. 2009. "Institutions, economic freedom, and cross-country differences in performance." Southern Economic Journal 75: 937-956.

Gwartney, James D., Randall G. Holcombe and Robert A. Lawson. 2004. "Economic freedom, institutional quality, and cross-country differences in income and growth." Cato Journal 24: 205-233.

Gwartney, James D. and Robert A. Lawson. 2003. Economic freedom of the world: 2003 annual report. Vancouver: Fraser Institute.

Huang, Yasheng, Randall K. Morck and Bernard Yeung. 2004. "ASEAN and 
FTAA: External Threats and Internal Institutional Weaknesses.” Business and Politics 6(1): 1-43.

Jansen, Marion and Hildegunn K. Nordas. 2004. "Institution, Trade Policy and Trade Flows." CEPR Discussion Paper 4418. London: Centre for Economic Policy Research.

Kaufmann, Daniel, Aart Kraay and Massimo Mastruzzi. 2009. "Governance Matters VIII: Aggregate and Individual Governance Indicators 1996-2008.” World Bank Policy Research Working Paper Series No. 4978.

Levchenko, Andrei A. 2007. "Institutional Quality and International Trade." The Review of Economic Studies 74(3): 791-819.

Levchenko, Andrei A. 2013. "International Trade and Institutional Change." Journal of Law, Economics, and Organization 29(5): 1145-1181.

Lee, Keun and Byung-Yeon Kim. 2009. "Both Institutions and Policies Matters but Differently for Different Income Groups of Countries: Determinants of Long-Run Economic Growth Revisited." World Development 37(3): 533-549.

Mayer, Thiery and Soledad Zignago. 2011. "Notes on CEPII's Distances Measures: the GeoDist Database." CEPII Working Paper No. 2011 - 25.

Mendonca, Talles G. de, Viviani S. Lirio, Marcelo J. Braga and Orlando M. da Silva. 2014. "Institutions and Bilateral Agricultural Trade." Procedia Economics and Finance 14: 164-172.

Nguyen, Doanh K. and Tuan D. Tran. 2012. "Impacts of Intellectual Property Right Protection on ASEAN Exports: GMM Estimator.” Sogang IIAS Research Series on International Affairs 12: 99-125.

North, Douglass C. 1994. "Economic Performance Through Time." The American Economic Review 84(3): 359-368.

Nunn, Nathan. 2007. "Relationship-Specificity, Incomplete Contracts, and the Pattern of Trade." The Quarterly Journal of Economics 122(2): 569-600.

Ranjan, Priya and Jae-Young Lee. 2007. "Contract Enforcement and International Trade." Economics and Politics 19(2): 191-218.

Rodrik, Dani, Arvind Subramanian and Francesco Trebbi. 2004. "Institutions Rule: The Primacy of Institutions Over Geography and Integration in Economic Development." Journal of Economic Growth 9: 131-165.

Yu, Miaojie. 2010. "Trade, Democracy, and the Gravity Equation." Journal of Development Economics 91: 289-300. 


\section{APPENDIX}

A 1. ASEAN TRADE FLOWS BY BEC 1-DIGIT PRODUCT CLASSIFICATION, 2000-2013

\begin{tabular}{cccccccc}
\hline \multirow{2}{*}{ Year } & \multicolumn{3}{c}{ Value (US\$ billion) } & & \multicolumn{3}{c}{ Annual Growth Rate (\%) } \\
\cline { 2 - 3 } \cline { 7 - 8 } \cline { 6 - 8 } & Export & Import & Total Trade & & Export & Import & Total Trade \\
\hline 2000 & 363.9 & 419.5 & 783.4 & & 23.5 & 18.9 & 21.0 \\
2005 & 576.5 & 640.7 & 1217.2 & & 15.8 & 14.6 & 15.2 \\
2006 & 658.5 & 751.1 & 1409.6 & & 14.2 & 17.2 & 15.8 \\
2007 & 748.3 & 842.0 & 1590.2 & & 13.6 & 12.1 & 12.8 \\
2008 & 924.4 & 961.6 & 1886.0 & & 23.5 & 14.2 & 18.6 \\
2009 & 715.8 & 791.6 & 1507.4 & & -22.6 & -17.7 & -20.1 \\
2010 & 936.7 & 1027.5 & 1964.2 & & 30.9 & 29.8 & 30.3 \\
2011 & 1129.7 & 1213.8 & 2343.5 & & 20.6 & 18.1 & 19.3 \\
2012 & 1194.3 & 1221.9 & 2416.3 & & 5.7 & 0.7 & 3.1 \\
2013 & 1213.3 & 1235.7 & 2449.0 & & 1.6 & 1.1 & 1.4 \\
\hline
\end{tabular}

SOURCE: The authors' computation based on UN COMTRADE database. 


\section{A 2. MAJOR PARTNERS OF ASEAN EXPORTS}

\begin{tabular}{|c|c|c|c|c|c|c|c|c|}
\hline \multirow{2}{*}{ Country } & \multirow{2}{*}{ Year } & \multirow{2}{*}{$\begin{array}{l}\text { Total Export } \\
\text { (US\$ mil.) }\end{array}$} & \multicolumn{6}{|c|}{ Major partner (\%) } \\
\hline & & & Japan & China & US & Intra-ASEAN & EU & NAFTA \\
\hline \multirow{3}{*}{ Indonesia } & 2005 & 85.66 & 21.07 & 7.78 & 11.54 & 18.47 & 12.09 & 12.41 \\
\hline & 2010 & 157.78 & 16.34 & 9.95 & 9.06 & 21.14 & 10.93 & 10.01 \\
\hline & 2013 & 182.55 & 14.84 & 12.38 & 8.62 & 22.26 & 9.21 & 9.43 \\
\hline \multirow{3}{*}{ Malaysia } & 2005 & 141.62 & 9.42 & 6.56 & 19.64 & 26.02 & 11.82 & 20.65 \\
\hline & 2010 & 198.79 & 10.37 & 12.60 & 9.55 & 25.40 & 10.77 & 10.91 \\
\hline & 2013 & 228.52 & 11.08 & 13.47 & 8.08 & 28.03 & 9.08 & 9.00 \\
\hline \multirow{3}{*}{ Philippines } & 2005 & 41.25 & 17.47 & 9.88 & 18.04 & 17.33 & 17.00 & 18.99 \\
\hline & 2010 & 51.50 & 15.23 & 11.12 & 14.70 & 22.42 & 9.76 & 15.87 \\
\hline & 2013 & 53.98 & 21.16 & 12.19 & 14.51 & 15.96 & 11.44 & 15.97 \\
\hline \multirow{3}{*}{ Singapore } & 2005 & 229.65 & 5.46 & 8.60 & 10.39 & 31.32 & 12.16 & 11.04 \\
\hline & 2010 & 351.87 & 4.66 & 10.33 & 6.52 & 30.31 & 10.00 & 7.26 \\
\hline & 2013 & 410.25 & 4.30 & 11.79 & 5.84 & 31.39 & 7.82 & 6.46 \\
\hline \multirow{3}{*}{ Thailand } & 2005 & 110.11 & 13.65 & 8.30 & 15.46 & 21.77 & 13.66 & 16.82 \\
\hline & 2010 & 195.31 & 10.45 & 10.99 & 10.36 & 22.70 & 11.22 & 11.58 \\
\hline & 2013 & 228.53 & 9.73 & 11.92 & 10.07 & 25.96 & 9.66 & 11.53 \\
\hline \multirow{3}{*}{ Vietnam } & 2005 & 32.45 & 13.38 & 10.01 & 18.27 & 17.70 & 17.11 & 19.96 \\
\hline & 2010 & 72.24 & 10.70 & 10.72 & 19.73 & 14.35 & 15.73 & 21.52 \\
\hline & 2012 & 114.53 & 11.41 & 11.21 & 17.18 & 15.22 & 17.74 & 18.79 \\
\hline
\end{tabular}

SOURCE: The authors' computation based on the WITS-UNSD database with SITC Revision 2.

NOTES: In this table, intra-ASEAN trade includes ASEAN-6 and the other members: Brunei, Cambodia, Laos, and Myanmar; EU includes 28 members; NAFTA includes Canada, Mexico, and the United States. 


\section{A3. THE LIST OF 115 COUNTRIES INCLUDED IN THE STUDY}

\begin{tabular}{|c|c|c|c|}
\hline Albania & Denmark & Jordan & Poland \\
\hline Algeria & Dominican, Republic & Kenya & Portugal \\
\hline Argentina & Ecuador & Korea, Republic & Romania \\
\hline Australia & Egypt & Kuwait & Russia \\
\hline Austria & El Salvador & Latvia & Rwanda \\
\hline Bahamas, The & Estonia & Lithuania & Senegal \\
\hline Bahrain & Fiji & Luxembourg & Sierra Leone \\
\hline Bangladesh & Finland & Madagascar & Slovak Republic \\
\hline Barbados & France & Malawi & Slovenia \\
\hline Belgium & Gabon & Mali & South Africa \\
\hline Belize & Georgia & Malta & Spain \\
\hline Benin & Germany & Mauritius & Sri Lanka \\
\hline Bolivia & Ghana & Mexico & Sweden \\
\hline Botswana & Greece & Morocco & Switzerland \\
\hline Brazil & Guatemala & Mozambique & Tanzania \\
\hline Bulgaria & Guinea-Bissau & Namibia & Togo \\
\hline Burundi & Guyana & Nepal & Trinidad and Tobago \\
\hline Cameroon & Haiti & Netherlands & Tunisia \\
\hline Canada & Honduras & New Zealand & Turkey \\
\hline Chad & Hong Kong SAR, China & Nicaragua & Uganda \\
\hline Chile & Hungary & Niger & Ukraine \\
\hline China & Iceland & Nigeria & United Arab Emirates \\
\hline Colombia & India & Norway & United Kingdom \\
\hline Congo, Republic of & Islamic Republic of Iran & Oman & United States \\
\hline Costa Rica & Ireland & Pakistan & Uruguay \\
\hline Côte d'Ivoire & Israel & Panama & Venezuela \\
\hline Croatia & Italy & Papua New Guinea & Zambia \\
\hline Cyprus & Jamaica & Paraguay & Zimbabwe \\
\hline Czech Republic & Japan & Peru & \\
\hline
\end{tabular}




\section{ENDNOTES}

1 Established in 1967 with five original members: Indonesia, Malaysia, the Philippines, Singapore, and Thailand. Brunei Darussalam joined in 1984, Vietnam in 1995, Laos and Myanmar in 1997, and Cambodia in 1999.

2 The four dimensions used in Doyle and Martinez-Zarzoso (2011) are: (i) size of government, (ii) legal structure and security of property rights, (iii) access to sound money, and (iv) regulation of capital, labor, and business.

3 The gravity model is derived from physics. It was originally applied to explain bilateral trade flows between countries by Tinbergen (1962) and Linnenmann (1966).

4 The result of the Hausman test where the null hypothesis is that the preferred model. The random effects have a . Since this value $<0.05$, the random effects is not appropriate.

5 http://www.bls.gov/cpi/. 